\title{
Contraception Method Following Spontaneous Abortion in N'djamena Mother and Child Hospital
}

\author{
Gabkika Bray Madoué1*, Foumsou Lhagadang ${ }^{1,2}$, Saibana Gama², Abdelsalam Saleh ${ }^{1,2}$
}

\author{
*Corresponding Author \\ Gabkika Bray Madoué

\section{Article History} \\ Received: 14.11.2019 \\ Accepted: 21.11.2019 \\ Published: 30.11 .2019
}

1N'Djamena Mother and Child Hospital

2Faculty of Human Health Sciences

\begin{abstract}
Background: Contraception means prevention of pregnancy. This one can be immediately done following the processes insuring the emptiness of the uterus. The aim of the study was to show the characteristic of patients accepting contraception and the main used contraception method after abortion. Patients and method: This was a prospective survey of five months from 17 July $17^{\text {th }}$ to 201729 December 29th 2017 about contraception method following spontaneous abortion performed at N'djamena Mother and Child hospital. Results: 81 patients had accepted to use contraceptive method among 135 giving a frequency of $60 \%$. The age groups of $20-24$ years were more represented with $33.3 \%$. The majority of patients had chosen the injection method (67.9\%). Conclusion: Contraception methods are often used during spontaneous abortion. The injections methods are preferred.
\end{abstract}

Keywords: Contraception, spontaneous abortion, N'djamena Mother and Child hospital.

\section{INTRODUCTION}

Contraception means prevention of pregnancy. There are a number of different methods and it is important to choose one that best meets your needs and circumstances [1]. Abortions are circumstances allowing the prescription of contraceptive method. This one can be immediately done following the processes insuring the emptiness of the uterus. In Chad the prevalence of women using contraceptive method is $6 \%$ which corroboring with a high indices of fecundity (6.4) [2]. This situation is contrasting with the high mortality rate of 860 maternal deaths for 100000 living birth [2]. Then the way that can help to curb maternal mortality is the contraception. The management of the contraception following abortion is rare in our country.

The aim of the study was to show the characteristic of patients accepting contraception and the main used contraception method after abortion.

\section{Methods And Patients}

This was a prospective survey of five months from 17 July $17^{\text {th }}$ to 201729 December $2^{\text {th }} 2017$ about contraception method following spontaneous abortion performed at N'djamena Mother and Child hospital.

Patients admitted for spontaneous abortion were included. According to the African Society of Genecology and obstetrics, abortion includes the gestational age less those 28 weeks [3]. Before including the patient in our study her consent should be gotten after giving her some explanations. Patients who refused to participate and those with other diagnoses were excluded. The contraception was proposed after insuring the emptiness of the uterus (patients with complete or incomplete abortion). Studied variables were: epidemiological, clinics. Data were collected and analyzed using EPI INFO 3.5.1 software.

\section{RESULTS}

\section{Epidemiological Aspects}

All patients admitted for spontaneous abortion had received before leaving the hospital the information about contraceptive method. Only 81 patients had accepted to use contraceptive method among 135 giving a frequency of $60 \%$.

Copyright @ 2019: This is an open-access article distributed under the terms of the Creative Commons Attribution license which permits unrestricted use, distribution, and reproduction in any medium for non commercial use (NonCommercial, or CC-BY-NC) provided the original author and source are credited. 
Table-1: Epidemiological Aspects

\begin{tabular}{|l|l|l|}
\hline Epidemiological aspects & $\mathbf{n}$ & $\mathbf{\%}$ \\
\hline$\underline{\text { Age }}$ & & \\
\hline $15-19$ & 06 & 07.4 \\
\hline $20-24$ & 27 & 33.3 \\
\hline $25-29$ & 24 & 29.6 \\
\hline $30-34$ & 08 & 09.9 \\
\hline $35-39$ & 11 & 13.6 \\
\hline $40-44$ & 05 & 06.2 \\
\hline Level of schooling & & \\
\hline Primairy & 10 & 12.3 \\
\hline Secondary & 49 & 60.5 \\
\hline university & 04 & 04.9 \\
\hline Non schooled & 18 & 22.2 \\
\hline
\end{tabular}

The age groups of $20-24$ years were more represented with $33.3 \%$. The mean age were $24.7 \pm 2.34$ years. Patients with secondary level had represented $60.5 \%$.

Table-2: Clinical aspects

\begin{tabular}{|l|l|l|}
\hline Clinical aspects & $\mathbf{n}$ & $\mathbf{\%}$ \\
\hline Terme & & \\
\hline First trimestre & 61 & 75.4 \\
\hline Second trimestre & 20 & 24.6 \\
\hline Type of abortion & & \\
\hline Incomplet & 55 & 67.9 \\
\hline Complet & 26 & 32.1 \\
\hline
\end{tabular}

The majority of abortion occurred in the first trimester of pregnancy (75.4\%).Incomplete abortion had represented $67.9 \%$.

Table-3: Type of Contraception

\begin{tabular}{|l|l|l|}
\hline Types of contraception & $\mathbf{n}$ & $\%$ \\
\hline Injection & 55 & 67.9 \\
\hline Implants & 11 & 13.6 \\
\hline Pills & 15 & 18.5 \\
\hline Total & 81 & 100,00 \\
\hline
\end{tabular}

The majority of patients had chosen the injection method $(67.9 \%)$

\section{DISCUSSION}

Only 81 patients had accepted to use contraceptive method among 135 giving a frequency of $60 \%$. This frequency is smaller than that reported by Benson in Peru in 2001 [4] noting $80 \%$ of patients that had accepted to use contraception after abortion. This proportion in higher that the national prevalence of the contraceptive use which is estimated at $6 \%$ [2]. This result can be explained by the fact that our patients are young a sexually active. The majority (60.5\%) had a secondary level and had had information about contraception in the school. It had been shown that the contraception is the way to avoid pregnancy after an abortion. An ovulation period can occur in the 2 nd to the $4^{\text {th }}$ week that following abortion and $75 \%$ of patients will have the ovulation in the six incoming weeks [5]. Despite the term of the pregnancy and the type of abortion (complete or not), the contraception method is necessary [1]. This assertion is applicable in our context, the majority of patients had carried a pregnancy for the first trimester $(75.4 \%)$ and the abortion was incomplete in $76.9 \%$. Our attitude conform some data's that showed the contraception as the way to space the birth and is important for the women and child. After a miscarriage an induced abortion, women have to wait at less 6 month to be pregnant, which can reduce the risk of maternal anemia fetal growth restriction , miscarriage and membrane ruptured [1].

Nowadays, there are many contraceptive methods. Each method has its indications, contra indications and side's effects. The efficiencies is variable, and there is not a contraceptive hormonal method with effectiveness of $100 \%$ [5]. In Chad contraception method are under the control of the government. All methods are free in the government Health Center. The choice of patients will depend of the clinical aspects and their antecedents. Main contraceptives methods available are: injection, pills, implant, and condom and intra uterine device. In this study, the majority $(67.9 \%)$ had chosen the injection method. Our result is higher than what reported by Foumsou [6] which was $58.6 \%$. The increasing of this rate can be explained by the fact that our study was carried on immediately after 
abortion and the need of contraception is high comparing with the Foumsou'study that was performed in the same city recruiting safe women.

\section{CONCLUSION}

The frequency of contraception after abortion is higher than the national frequency; the injection is the most use contraception method.

Author's Approval: All authors approve the submission of this work.

Conflict of Interest: All authors have declared that there is no conflict of interest.

Funding: No financial assistance or grants were solicited or obtained during the course of preparing this article

\section{RefERENCES}

1. Planification familiale après avortement: Renforcer la composante de planification familiale des soins après avortement novembre 2012. https://www.fphighimpactpractices.org/wpcontent/uploads/2018/08/PHI_Planification-familiale-aprèsavortement.pd

2. Enquete demographique et de santé du tchad 2015.

3. Recommandations pour la pratique clinique des soins obstétricaux et néonatals d'urgence. SONU Afrique 3ième edition https://www.gieraf.org/assets/images/article_41/01SONU\%20AFRIQUE\%203\%C3\%A8me\%20\%C3\%A9dition\%202018.pdf

4. Benson, J., \& Huapaya V. (2002). Sustainability of postabortion care in Peru. New York: Population Council, 45.

5. WHO/RHT/97.20. Planification familial après avortement. Guide pratique à l'intention des responables de programmes. 95 . https://www.sagesfemmesorthogenistes.org/wpcontent/uploads/2012/07/OMSPLANIFICATIONFAMILIALE-APRESAVORTEMENT1.pdf

6. Foumsou, L., Dangar, G. D., Djimasra, T. O., Mémadji, M., Mignagnal, K., \& Mboudou, E. T. (2015). Problématique de la Planification Familiale dans les Hôpitaux de la ville de N'Djamena. Revue Scientifique du TCHAD, 1(8), 29-35. 